\title{
Yaşlılık ve Yaşlılara Sunulan Psikolojik Danışma ve Rehberlik Uygulamalarına Bir Bakış
}

\author{
Arş. Gör. Çiğdem DEMİR ÇELEBİ* \\ Marmara Üniversitesi, Atatürk Eğitim Fakültesi, Eğitim Bilimleri Bölümü, \\ Kadıköy / İstanbul / Türkiye

\section{Doç. Dr. Müge YUKAY YÜKSEL} \\ Marmara Üniversitesi, Atatürk Eğitim Fakültesi, Eğitim Bilimleri Bölümü, \\ Kadıköy / İstanbul / Türkiye
}

\section{Özet}

Bu araştırmanın amacı, dünyada ve Türkiye'deki yaşlı nüfusun durumuna ve yaşlılara sunulan hizmetlere, psikososyal açıdan 1şık tutmak ve özellikle yaşlılara sunulan rehberlik ve psikolojik danışmanlık uygulamalarına ilişkin bilgi vererek yaşlılık hizmetlerini psikolojik açıdan ele almaktır. Çalışmada veriler, literatür taraması modeli kullanılarak edinilmiştir. Genel olarak yaşlılığın tanımı, dünyada ve Türkiye'de yaşlılığın durumu ile yaşlılara sunulan psikososyal hizmetler hakkında bilgi verilmiş; psikolojik danışmanlık ve rehberlik uygulamalarına değinilmiştir. Sonuç ve öneriler kısmında, sunulan psikososyal hizmetler kısaca özetlenerek bir durum tespiti yapılmış ve eksik görülen kısımlar için öneriler sunulmuştur.

Anahtar Kelimeler: Yaşlı; Psikolojik danışmanlık ve rehberlik; Danışmanlık becerileri.

* Sorumlu Yazar. Tel: +905418587724 E-posta: cigdem.demircelebi@ gmail.com

(C) 2014 Kalem Eğitim ve Sağlık Hizmetleri Vakfi. Bütün Hakları Saklıdır. ～ISSN: 2146-5606 


\title{
Elderliness and A Review of Psychological Counseling and Guidance Services for Elderly People in Turkey
}

\begin{abstract}
The aim of the present study was to present elderly population in the world and Turkey in addition to inform about psychological counseling and guidance services for elderly people and to determine deficiencies at this point. Data was gathered by literature review method. This study provided information about the definition of senility together with case of elderly population and psychological counseling and guidance services in the world and Turkey. Psychosocial services were summarized and offered suggestions to develop these services in the part of conclusion and suggestions.
\end{abstract}

Keywords: Elder; Psychological counseling and guidance; Guidance skills.

\section{Extended Summary}

In recent years, examined the statistics of population, it's seen that elderly population increases day by day both in the world and Turkey. Decreasing of young population and increasing old age population causes economic, psychological, social and health problems affecting both elder, and the people who live with them on this period.

Social policies and psychosocial services facilitating elder to live together in harmony with the society have importance for old age problems to be prevented and solved seemly. It's important for elder to be supported in every respect by collaboration of all the systems serving elderly people.

Psychological counseling and guidance services are also sub- 
stantial for elderly people to get ready for this period, to strengthen the self and to cope with adaptation to elderliness and psychological problems of this period. Psychological counselors have also significant roles to strengthen the elderly people and to make them get a happy life.

In this study, it's submitted the elderly population in Turkey and the world, old age problems, elderly services, and psychological counseling and guidance applications for elders. At the end of the study, some suggestions are given subsequent to present the deficiencies on this point in Turkey.

\section{Giriş}

Dünyada ve Türkiye'de nüfûs istatistiklerine bakıldığında son yıllarda yaşlı nüfûsta oldukça belirgin bir artış görülmektedir. Genç nüfûsun azalması ve yaşlı nüfûsun artması, bu dönemle ilişkili sorunları da beraberinde getirmiştir. Yaşlı bireyin hayatındaki ekonomik, psikolojik, sosyal ve sağlıkla ilgili değişiklikler ile sorunlar yaşlıyı ve onunla yaşayan herkesi etkilemektedir.

Yaşlı problemlerinin önlenmesi ve uygun yollarla çözülmesi için yaşlı bireyin ve toplumun uyum içinde yaşamasına yardımcı olacak sosyal politikalar ve psikososyal hizmet uygulamaları büyük önem arz etmektedir. Türkiye'de yaşlı hizmetleri incelendiğinde bu hizmetlerin ilk defa 1963 yılında Sağlık Sosyal Yardım Bakanlığı'na bağlı Sosyal Hizmetler Genel Müdürlüğü'nün kurulmasıyla kamu hizmetleri içerisindeki yerini aldığı görülmektedir. 1982 Anayasası'nın 61. maddesinde yaşlılara yönelik olarak "Yaşl1lar devletçe korunur. Yaşlılara 
devlet yardımı ve sağlanacak diğer haklar ve kolaylıklar kanunla düzenlenir." hükmü yer almaktadır (Akgün, Bakar ve Budakoğlu, 2004). Ankara Büyükşehir Belediyesi bünyesinde 1994 yılında kurulan 'Yaşlılara Hizmet Merkezi'nde uygulanan 'Evde Bakım Projesi', alanında ilk olup, üye olan yaşlılara; evde sağlık, evde takip hizmetleri, evde yardım, evde bakım-onarım hizmeti verilmiş; sadece sağlık ve temizlik hizmeti karşılığında cüzi bir para alınmış ve hizmete talep oldukça yüksek olmuştur. Evde yaşlı bakımı için eleman yetiştirme amaçlı "Yaşlı Bakıcılarının Eğitimi” projesine ilişkin protokol ise SHÇEK Genel Müdürlüğü - Millî Eğitim Bakanlığı - Millî Eğitim Sağlık Eğitimi Vakfı arasında 23.12.1999 tarihinde imzalanmış, SHÇEK-MEB arasındaki koordineli bir çalışmayla "Yaşlı Bakım Elemanı Eğitimi Müfredat Programı” 2000 yılında geliştirilmiş ve Ankara Emek 100.Y11 Kız Meslek Lisesi'nde eğitim öğretim müfredâtına eklenmiştir. İstanbul Büyükşsehir Belediyesi'ne bağlı İstanbul Sağlık A.Ş. bünyesinde ise, yaşlı hastalar için evde sağlık destek hizmetleri, ücretli tıbbî bakım-refâkat hizmetleri, 2001 yılından bu yana doktor, bakım hemşiresi, hasta takip hemşiresi, fizyoterapist, sosyal hizmet uzmanı, psikolog ve bakım destek personelinden oluşan profesyonel bir ekiple yürütüldüğü bilinmektedir. SHÇEK Yaşlı Danışma Merkezleri süreç içerisinde üye olan yaşlıların sosyal-kültürel aktivitelere katıldığı, birbirleri ile dayanışma içine girdikleri merkezler hâline dönüşünce, 2001 yılında adı 'Yaşlı Dayanışma Merkezi'ne dönüşmüş; Alzheimer hastası yaşlıların gündüz bakımlarını sağlayarak yaşlıya ve ailesine destek hizmetleri sunmak amaciyla SHÇEK Genel Müdürlügü̈, Ankara Yenimahalle Kaymakamlığı ve Alzheimer Derneği arasında imzalanan protokol 
gereği Ankara Ümitköy Huzurevi Müdürlüğü'ne bağlı olarak açılan Batıkent Alzheimer Hastası Yaşlılar Gündüzlü Bakım Merkezi 20.03.2003 tarihinde hizmete açılmıştır. Merkez Danışma Kurulu'nun kararıyla 2006 y1lı Haziran ayından bu yana etkinliklerini huzurevi bünyesinde ise özürlü yaşlı bireyin hayatının öncelikle bulunduğu ortamda sürdürmesi amacıyla belli esaslar dâhilinde bakım gereksinimi sunulmakta, özürlü yaşlının evde bakımı sağlanmakta ve akrabasına net asgarî ücret tutarında SHÇEK tarafindan ödeme yapılmaktadır. SHÇEK tarafından temel ihtiyaçlarını karşılayamayan ve hayatlarını en düşük düzeyde dahi sürdürmekte güçlük çeken korunmaya, bakıma ve yardıma muhtaç yaşlılara ve ailelerine aynî-nakdî yardım sağlanmaktadır (Devlet Planlama Teşkilatı, 2007).

Yaşlı bireylerin huzurlu bir ömür sürmeleri için yaşlıyla ilgili bütün sistemlerin birlikte çalışmaları önemli bulunmaktadır (MacAdam, 2008). Yaşlı bireyin yaşlılık dönemine hazırlanması, kendini birçok bakımdan güçlendirmesi ve yaşadığı uyum problemleri ve diğer psikolojik sıkıntılarının atlatılması bakımından psikolojik danışmanlık ve rehberlik hizmetleri de önemlidir. Yaşlının güçlendirilmesi ve mutlu bir hayat sürdürmesi için psikolojik danışmanlara büyük roller düşmektedir. $\mathrm{Bu}$ çalışmada, yaşlılar için psikolojik danışmanlık ve rehberlik hizmetlerinin önemine dikkat çekilerek dünyada ve Türkiye'de yaşlı nüfus, yaşlıların yaşadıkları problemler, yaşlılara sunulan hizmetler ile psikolojik danışmanlık ve rehberlik uygulamalarına yer verilmiştir. Çalışmanın sonunda, Türkiye'deki yaşlıların durumu psikolojik yönden ele alınarak tartışılmıştır. 


\section{Yaşlılığın Durumu ve Sorunları}

Yaşl1lık, günümüzde sadece biyolojik yaşla ifade edilen bir kavram değildir. Yaşlılığın tanımı, kişinin kendini yaşlı hissetmesiyle açıklanmaktadır. Yaşlılık, bireysel özelliklere göre gerek fiziksel, gerek psikolojik olarak farklılaşmaktadır. Ancak, Dünya Sağlık Örgütü (DSÖ), yaşlılığ 1 biyolojik yaş ölçütüne göre dört grupta incelemektedir: DSÖ’ye göre 45-59 yaşlar arasındaki bireyler, orta yetişkin; 60-74 yaş arası bireyler, yaşlı; 75- 89 yaş arası bireyler, ileri yaşlı; 90 ve üstü bireyler çok yaşı (ihtiyar) olarak sınıflandırılmaktadır.

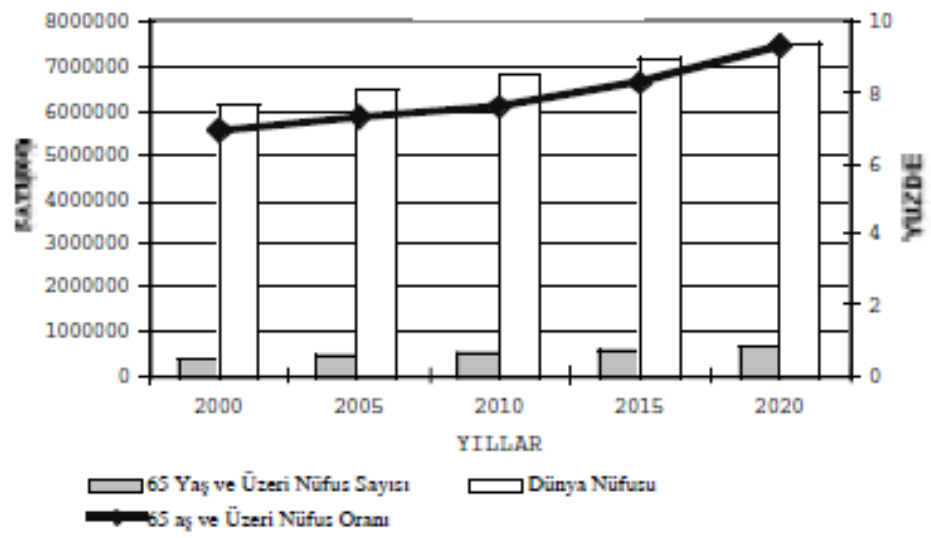

Şekil 1. 2000-2020 Y1lları Arasında Dünyada Toplam Nüfûs, 65 Yaş ve Üzeri Nüfûs ve Oranın Değişimi (WHO, 2002)

2000-2020 yılları arasında dünyadaki toplam nüfûs tablosuna baktığımızda (Şekil 1), 65 yaş ve üstü nüfusun, özellikle 2010 yılından sonra yüksek bir artış gösterdiği görülmektedir. Bu hızlı artış, göz önünde bulundurulduğunda gelecekte, yaşlı nüfusun toplam nüfûsta büyük bir yer tutacağı söylenebilir. 
Artan yaşlı nüfûs oranı ile birlikte dünyada ve ülkemizde yaşlı nüfûsla birlikte yaşlıların yaşadıkları sorunlar da ön plâna çıkmaktadır. Yaşlıların yaşadıkları problemler arasında ekonomik sıkıntılar, bedensel, ruhsal ve bilişsel sağlık problemleri (Güven ve Şener, 2010; Dönmez, 2010), barınma sorunları ve yaşlılığa uyum sorunları ile yaşlının bakıma muhtaç hâle gelmesi (Arslan ve Bölükbaş, 2003), çevresiyle iletişimde problemler yaşaması, bazı yakınlarının kaybını yaşaması (Özer, 2001), çocukların evden ayrılması (İçli, 2010; Mutlu, 2012) sayılabilir.

Subaşı ve Öztek (2006) tarafindan Ankara ili Çankaya ilçesinde 1055 hane üzerinde 18 yaş üzeri kişilerin yaşlı bakımı konusundaki düşüncelerini incelemek amacıyla yapılan araştırmada; araştırmaya katılanların \% 75.0'i kendilerine bakamayacak kadar yaşlanan ebeveyne çocuklarının bakması ve bakım yerinin yaşlı bireyin kendi evi olması gerektiğini belirtmişlerdir. Araştırma sonuçları, yaşlı bireylerin huzurevlerinde kendilerini soyutlanmış hissettikleri, yalnızlık ve tükenmişlik duygularına kapıldıkları ve ruhsal sorunlarının arttığı, kurumsal bakımdan yeme, içme, yatma ve temizlik gibi konularda memnun oldukları hâlde yine de kendi evlerinde kalmayı tercih ettiklerini göstermektedir. Kendi evinde ve huzurevinde yaşayan yaşlıların hayat doyumlarının karşılaştırıldı̆̆ evinde yaşayan yaşlıların hayat doyumlarının huzurevinde yaşayan yaşlılardan anlamlı düzeyde yüksek olduğu bulunmuştur (Arslan 2011; Özer, 2004; Özer, 2001). İçli (2010) tarafindan yapılan araştırmada huzurevinde yaşayan yaşlılardan eğitimi olmayan, dul/boşanmış olan, 
ziyaret edilmeyen ve aile içinde önemsenmediğini belirtenlerin depresyon puanı anlamlı düzeyde daha yüksek bulunmuştur.

Sağlık alanındaki hızlı gelişmeler, enfeksiyon ve hastalıklara bağlı ölümlerin azalması, doğuştan beklenen hayat süresinin uzaması, ailelerin az sayıda çocuk sahibi olması, insanların hayat standartlarının artması, çalışma ve emeklilik şartlarının değişmesi, sosyal sigorta sistemlerinin gelişmesi ve ekonomik standartların yükselmesi gibi nedenler yaşlı nüfûsun hızla artmasına neden olmaktadır (National Institute on Aging, 2007). Bu hızlı artışın olası sonuçlarından olumsuz etkilenmemek için gereken tedbirler alınmalı ve yaşlı bireylere ve ailelerine yapılacak hizmetler artırılmalıdır.

\section{Yaşı Hizmetlerinde Dikkat Edilecek Hususlar}

Yaşlilara sunulan hizmetlerdeki temel amaç, onların kendilerine yetebilen mutlu birer birey olmalarını sağlamaktır. Bu hizmetlerin alınması yaşılıar açısından bir hak olduğu kadar, diğerleri açısından da bir görevdir (Ersanl1, 2008). Yaşlılara ve müstakbel yaşlı adayları olan gençlere refah içinde bir hayat sürmek için devlet ve vatandaşlar, üzerine düşen görevi yerine getirmelidir.

Yaşl1lar için verilecek hizmetin temel amaçları; kendi evlerinde bağımsız, rahat ve huzurlu bir şekilde yaşamalarını sağlamak; yaşlılık, evsizlik, bakım gereksinimi gibi durumlara uyum sağlayabilecekleri alternatif yerleşim olanakları sunmak; fiziksel ya da mental hastalık nedeniyle gereksinim duyulan durumlarda uygun hastane koşulları oluşturmak şeklinde özetlenebilir (Gökkoca ve Baharlıetiler, 1999). 
Bir toplumda yaşlıların huzur içinde bir ömür sürmeleri, yaşlılar açısından mutluluk verici olduğu kadar, genç kuşakların geleceğe umutla bakması açısından da önemlidir.

Yaşlilara sunulan hizmetler düzenlenirken, yaşliların bu dönemde yaşadıkları problemler hakkında bilgi sahibi olunmalıdır. Yaşlıların yaşadıkları sorunların, psikolojik, sosyal, biyolojik, fiziksel ve ekonomik yönleri tek tek ele alınmalı; bir bütün hâlinde gerekli değişiklikler yapılmalıdır.

\section{Yaşılılara Sunulan Psikolojik Danışmanlık ve Rehberlik Hizmetleri}

Yaşlılarla psikolojik danışmanlık uzmanlığının yaklaşık yirmi yıllık bir geçmişi vardır. Son yıllarda yaşlılara sunulan danışmanlık uygulamalarında bir takım standartlar geliştirilmiştir. Yaşlılarla ilgili konularda uzmanlaşmanın yaşlı kişilerin ihtiyaçlarına en iyi şekilde hizmet edip edemeyeceği sorusu hâlâ bu alanda hizmet verenlerin tartışmalarının odak noktasıdır (Myers, 1995).

Yaşlilara sunulacak hizmetlerde özellikle sosyal içerikli koruyucu önlemlere yer verilebilir. Bu önlemlerden bazıları şu şekilde s1ralanabilir:

- Yaşlıların sosyal hayata katılımlarını sağlama,

- Kendilerini çeşitli alanlarda geliştirmelerine destek olma,

- Eğitim alma / verme hareketlerine katılımlarını sağlama,

- Üretkenliklerini sürdürebilmelerine ortam hazırlama,

- Kuşaklararası paylaşımı arttırıcı projeleri yaşama geçirme,

- Her alanda ve düzeyde (merkezî-yerel) demokratik haklarını 
kullanabilmeleri için plânlamalar yapma,

- Karar alma sürecinde yaşlilara destek amaçlı çalışan sivil toplum kuruluşlarına aktif katılım sağlanmasına destek olma.

Yaşlı bireylerin psikolojik gelişimlerinde ise; kendi kendilerine yeterli olabilmelerinin özendirilmesi, aktif ve sağlıklı hayat tarzının benimsetilmesi ve sürdürülmesine ilişkin programlar geliştirilmesi ve çeşitli destek programlarının oluşturulması mümkündür (Yazıcıoğlu, 2010).

Erikson'un (1963) psikososyal gelişim kuramına göre ileri yetişkinlik döneminde bireyde ego bütünlüğ̈̈ ya da umutsuzluk duygularından biri hâkimdir. Ego bütünlüğüne sahip bireyler, geleceğe umutla bakar ve hayatı olumlu ve olumsuz yönleriyle kabul edip kendiyle ve çevresiyle uyum içindedir. Kişi, ölümü de olgunlukla karşılayıp ondan korkmaz. Umutsuzluk duygusu yaşayan bireyler ise, geçmişe yönelik büyük bir pişmanlık ve memnuniyetsizlik yaşamaktadırlar. $\mathrm{Bu}$ bireyler, çevrelerindeki kişilerle olan ilişkilerinde de problem yaşamaktadırlar. Erikson'un görüşlerine bakıldığında, bu dönemde bireylerin psikolojik açıdan problem yaşama risklerinin olduğu görülmektedir. Yaşlı bireyin, bu döneme girmeden önce güçlendirilmesi ve problem yaşadığında çözümünde yardımcı olmak amacıyla psikolojik danışmanlık hizmetlerinin yararlı olacağı söylenebilir (Bacanlı ve Iş1k-Terzi, 2013; Can, 2012; Corey, 2008).

Yaşlılık kuramlarında sıkça bahsedilen durumlardan biri yaşl1larda görülen ölüm kaygısıdır (Karaca, 2000; Pollack, 1980). Yurt 
dışında yaşlılarla ilgili yapılan çalışmalara bakıldığında, bireyin ölümü kabul etmesi, ona hazırlanması ve ondan korkmaması için psikolojik danışmanlık hizmeti verildiği görülmektedir (Aditi-Singh, Singh ve Nizamie, 2003; Fortner ve Neimeyer, 1999).

Yaşlılık döneminde bireyin hayatında yaşanan bir diğer değişiklik ise rol geçişleridir. Yaşlı birey, iş yaşamından ayrılma ve emekliliğin başlaması, boş zamanların artması ve çocukların evden ayrılmasıyla uyum sorunu yaşayabilir (Onur, 2011). Bu dönemde, birey, hayatın yeniden gözden geçirilmesi ve düzenlenmesi konusunda psikolojik danışmadan yararlanabilir.

Yaşlılık dönemindeki ekonomik sıkıntılar; bedensel, ruhsal ve bilişsel sağlık problemleri; barınma sorunları ve yaşlılığa uyum sorunları ile yaşlının bakıma muhtaç hâle gelmesi (Arslan 2011; Özer, 2004; Özer, 2001); çevresiyle iletişimde problemler yaşaması; bazı yakınlarının ölmesi (Çevik-Sökmen, 2008); çocukların evden ayrılması gibi sorunlar ile günlük hayatın getirdiği stres (Bahar, Tutkun ve Sertbaş, 2005; Altıntaş, Atilla, Sevencan, Akçalar, Sevim ve Solak, 2006) gibi problemlerin aşılması konusunda psikolojik danışmanlara büyük roller düşmektedir.

Yaşlılıkla ilgili psikolojik danışmanlık ve rehberlik çalışmaları, diğer gelişim merhalelerinde yapılan psikolojik danışma faaliyetlerinde olduğu gibi; uyum sağlayıcı, yöneltici, ayarlayıcı, önleyici, gelişimsel, tamamlayıcı ve kriz odaklı olarak ele alınabilir (Gladding, 2013). Yetişkinlik döneminde uygulanan psikolojik yardımla yaşlılığa hazırlanan 
birey, bu dönemde yaşayabileceği olası problemlerin de farkında olur ve bu süreçten daha az etkilenir. Ayrıca rehberliğin çocukluk döneminden ergenliğe geçişe yönelik yaptığı hazırlık faaliyetlerinin benzeri yetişkinlikten ileri yetişkinliğe geçiş sürecinde menopoz ve andropoza hazırlık olarak bireylere programlar, seminerler ve bilgi verici danışmanlık hizmetleri aracılığıyla sunulabilir. Bu bakımdan, önleyici ve uyum sağlayıcı rehberlik ve psikolojik danışmanlık hizmetleri önem kazanmaktadır. $\mathrm{Bu}$ dönemde bireyi güçlü kılmak için farkındalığının artırılması ve yeni bir yaşam plânı da hazırlanabilmektedir. Yaşlılara hizmet verilen kurumlarda rehberlik ve psikolojik danışma merkezlerinde, ayarlayıcı rehberlik kapsamında çalışma plân ve programları hazırlanarak yaşlilara maksimum fayda sağlayacak uygulamalar belirlenebilir. Yaşlilara gelişimsel rehberlik hizmetleri bağlamında da hayatın bütün dönemlerini içeren yöneltici ve gelişimsel hizmetler sunulabilir. Bunlar; çalışma hayatından emekliliğe geçiş, kariyeri yeniden gözden geçirme, çocukların evlenerek yuvadan ayrılmasından sonra tekrar çift hâline gelebilme gibi konuları içerebilir. İlerleyen yaşla beraber azalan bilişsel işlevler, yaşlıların yetişkinlik yıllarında karşılaştıkları problemleri çözmede gerekli manevraları yapmalarına olanak tanımayabilir. Kriz odaklı rehberlik çalışmaları kapsamında yaşlılara, âni kayıplar ve âni beliren hastalıklarla başa çıkma becerileri kazand1rilabilir.

Yaşlılarla psikolojik danışmanlık uygulamaları 1970'lerden itibaren önem kazanmıştır. Gerek bireysel, gerek grupla psikolojik danışmada birçok kuramsal temelden faydalanılmıştır. Kaygusuz ve 
Kalkan (2008), yaşlılara uygulanan psikolojik danışmanlık yaklaşımlarını a) Psikodinamik yaklaşım, (b) Destekleyici yaklaşım, (c) Bilişseldavranışçı yaklaşım, (ç) Grupla psikolojik danışma ve (d) Aile danışmanlığ1 olmak üzere beş ana grupta toplarken; Göka ve Aydemir (2000), bu yaklaşımları dört genel kategori altında ele alıp bu kategorileri kendi içinde gruplara ayırmaktadır. Göka ve Aydemir (2000) tarafından sınıflanan yaşlılık danışmanlığı kategorileri aşağıdaki gibidir:

- Bireysel dinamik psikoterapiler

- Kısa süreli (zaman sıralı) psikoterapi

- Psikoanalitik (içgörü yönelimli) psikoterapi

- Dinamik olmayan psikoterapiler

- Destekleyici psikoterapi

- Bilişsel-davranışçı terapi

- Seks terapi

- Yaşamı gözden geçirme terapisi

- Aile terapisi

- Grup psikoterapileri

Psikodinamik terapiler bireyin bugünkü davranışının bilinçaltı süreçlerini inceleyen bir danışma yaklaşımıdır. $\mathrm{Bu}$ yaklaşımın ana amaçları danışanın öz farkındalığını sağlamak ve geçmişin şimdiki davranışlarına olan etkisini görmesine yardımcı olmaktır. Yaşlılarla yürütülen bireysel dinamik psikoterapiler ise kısa süreli ve psikoanalitik psikoterapi olmak üzere iki alt başlık altında ele alınmaktadır. Bireysel psikodinamik yaklaşımda danışma oturumlarının en az iki yıl 
sürmesinin dezavantajının fark edilmesi sonucu ortaya çıkmış olan ve genellikle en fazla 25 oturum süren kısa süreli psikodinamik yaklaŞımda danışanın geçmiş yaşantıları ve geçmişteki işlevsel olmayan ilişkilerinin yol açtığ çatışma ve semptomlarını fark etmesine odaklanılmaktadır (Substance Abuse and Mental Health Services Administration, 2012). Morgan (2003)'a göre yaşl1larla yürütülen psikodinamik yaklaşımlarda da gençlerde olduğu gibi empatik dinleme, keşfe dayalı sorgulama, yansıtma gibi tekniklerden faydalanılır. Ancak yaşlılar, bireysel danışma seansına hem gençlerin sahip olduğu hem de yaşlıl1ğın getirdiği pek çok problemle gelebilir. Bu açıdan psikolojik danışmanın oldukça yeterli olması gerekir. Ayrıca danışma sürecinde transferans, direnç ve karşıt transferansın özellikle üzerinde durulması beklenir.

Yaşlılarla yürütülen psikolojik danışma yaklaşımlarının ikincisi dinamik olmayan psikoterapiler başlığ 1 altında ele alınmakta ve destekleyici psikoterapi, bilişsel-davranışçı terapi, seks terapisi ve hayatı gözden geçirme terapisi başlıklarını içermektedir. Destekleyici terapiler, hastanın hastalık belirtilerini iyileştirmek, hastalıktan edindiği ikincil kazançları azaltmak ve ilaç tedavisi görüyorsa tedaviye uyumunu artırmak için kullanılmaktadır. Bu terapi yaklaşımı, özellikle beyin hasarlı yaşlı bireyle yaşayan aile bireylerinin tükenmişliklerini ve çaresizliklerini ortadan kaldırmada da etkili bir yaklaşımdır (Kaygusuz ve Kalkan, 2008).

Dinamik olmayan psikoterapi yaklaşımlarından bir diğeri de bilişsel davranışçı yaklaşımdır. Bireyin çevrenin kendisinden çok kendi 
zihnindeki bilişsel tasarımına cevap verdiğini ileri süren bilişsel davranışçı yaklaşımda danışanla işlevselliği bozuk bilişsel süreçler ile onlara eşlik eden duygu ve davranış örüntüleri üzerinde çalışılır (Türkçapar, 2012). Danışma oturumlarında işbirliği sağlama, müdahale noktalarını ve müdahale stratejilerini belirleme ve sorulara rehberlik etme, ev ödevlerini seçme gibi müdahale tekniklerinden faydalanılabilir (Thompkins, 2007). Yapılan araştırmalar bilişsel davranışçı yaklaşımın, depresyon, kaygı, alkol bağımlılığı, insomnia ve diğer fiziksel rahatsızlıklardan muztarip yaşlılar üzerinde olumlu etkisi olduğunu göstermektedir (Satre, Knight ve David, 2006).

Yaşlı birey, pek çok sağlık probleminin yanında cinsellik konusunda da değişikliklerle karşılaşabilir. Yaşlı erkeklerde ereksiyonun daha yavaş başarılması ve daha doğrudan genital uyarıma ihtiyaç duyma gibi değişiklikler görülürken yaşı kadınlarda ise yağ dokusundaki azalma nedeniyle vajen yağlanmasında ve esnekliğinde azalma ile yağlandırıcılar kullanmadıkça cinsel ilişki sırasında ağrı duyulması gibi sorunlarla karşılaşılabilmektedir. Bu işlev bozukluklarının yanında bazı hastalıklar ve ilaç kullanımları da yaşıının cinsel yaşamını etkileyebilmektedir. $\mathrm{Bu}$ bakımdan yaşlı bireyler seks terapisine alınmadan önce tetkiklerinin uygun biçimde tamamlanması gerekmektedir (Göka ve Aydemir, 2000). Yapılan araştırmalar incelendiğinde Türkiye'de en çok yaşlı ve bekâr kadınların cinsel işlev bozukluk yaşadığını ortaya koymaktadır (Cinsel Eğitim Tedavi ve Araştırma Derneği, 2006). Belirtilen fizyolojik sorunların çeşitliliği nedeniyle yaşlılarla psikolojik danışma yapacak profesyonellerin uzman olması gerekmektedir. Seks 
terapisinde yaşlı birey ve eşine güvenli bir biçimde cinsel ilişki kurma ile ilgili bilgi verilebilir, cinsel ilişki esnasında karşılaşabilecekleri sorunlar açıklıkla konuşulabilir (Kaygusuz ve Kalkan, 2008).

Dinamik olmayan psikoterapilerden olan hayatı gözden geçirme terapisinin temeli, yaşlı bireyden ve ailesinden özgeçmiş öyküsü toplanması esasına dayanır. Yaşlı bireyler, geçirdikleri yıllara baktıklarında hayatta başardıklarını dikkate almazlar ve hep başarmak isteyip de başaramadıkları şeyler için üzüntü duyarlar. Bu bağlamda yaşlıların geçmişlerine sık sık atıfta bulunmaları, geçmişi düşünme ve analiz etme isteğinin dış dünyaya yansıması şeklinde değerlendirilebilir. Dolayısıyla bu süreç yaşlı birey için etkin bir süreçtir. İkinci terapi yöntemi ise hayat döngüsü grup terapisidir. Söz konusu terapiye, ergenlik ile yaşlılık döneminin son sınırına kadar olan her gelişim dönemi bireyleri katılabilir. $\mathrm{Bu}$ yaklaşımın esasını da yaş ayrımına gitmenin kuşaklar arası diyalogu engellediği tezi oluşturur (Onur, 2011).

Aile desteği olmadan yaşlı hastaların bilişsel bozukluklarıyla ilgilenilirse çok yol alınamayacağı âşikârdır. Ailenin desteği alınmadan daha doğrusu aile bir bütün olarak ele alınmadan sorunlara çözüm aramak işe yaramayacak hatta sadece hasta ile ilgili olmaktan çıkıp bütün aileyi derinden etkileyecektir. Ailenin yaşlı bir üyesinde bilişsel bir bozukluk ortaya çıktığında ailedeki rol dağılımlarının hemen altüst olacağı görülecektir. Aile tedavisine başlamanın en iyi yolu hastanın yaşadığ 1 durumları ailenin nasıl algıladığ1 ve bu durumların ortaya çıkmasının aileleri nasıl etkilediği üzerine eş duyumsal bir yaklaşım ve açıklamadır. Bu arada ailede özgün psikolojik rahatsızlıklar olup ol- 
madığı aile öyküsü alınırken ve gözlem sırasında anlaşılmaya çalışı1ır (Göka ve Aydemir, 2000). Özellikle Alzheimer gibi süreğen ve mental bir hastalığı olan yaşlılarla yaşayan ailelerle danışma uygulamaları gerçekleştirilerek aile bireylerinin çaresizlik ve suçluluk duyguları azaltılabilir; hasta yaşlıya karşı takındıkları tutum olumlu şekilde yönlendirilebilir.

Birey yaşlanırken hayatında da pek çok değişim yaşamakta, bir yandan fiziksel ve zihinsel yeterlikle ilgili sorunlarla baş etmeye çal1şırken, bir yandan da tanıdıklarının ölümleriyle yüzleşmektedir. Bu gibi durumlarda yaşlıya kendini yalnız hissettirmeyecek grupla danışma uygulamaları faydalı olabilir (Kaygusuz ve Kalkan, 2008). Yaşlılarla yürütülen grupla psikolojik danışma yaklaşımlarından biri Erikson'un ve Butler'ın teorilerini temel alan Anımsama Terapisi'dir. Genel olarak grupla psikolojik danışma kurallarının geçerli olduğu bu yaklaşımda, üç-sekiz üyenin anı paylaşımında bulunmak üzere bir araya geldiği anımsama gruplarında paylaşımların verimli olabilmesi ve her bir üyeye yeterince vakit ayrılabilmesi için üye sayısının 10'u geçmemesi beklenmektedir. Grupta üyelerin birbirleriyle gösterdikleri uyum göz önünde bulundurularak danışma oturumlarının sonlandırılması için kesin bir süre biçilmemektedir (Siviş, 2007).

Hayat döngüsü grup terapisinde yaşlıların kendini yenileme yeteneklerine daha fazla inanç ve güven duyulması gerektiği düşünülmektedir. Yaşlı bireylerin geçmişe bağımlı olmayan, hayatın içinde aktif bireyler olduğu vurgusu yapan yaklaşımda yaşlı bireylerin kendilerine özgü sorunlara karşın, ulaştıkları olgunluk, birikim ve doyum 
düzeyi ölçüsünde hayata bağlanma şansına sahip oldukları düşünülmektedir. Bu açıdan, yeterli bulunmayan edilgin yaşlı bakım hizmetleri yaşlı bireyleri aktif konuma geçirecek biçimde yeniden düzenlenmelidir. Yaşlılara, kendilerini yenileme olanağı veren uygun spor, grup psikoterapisi gibi etkinlikler de sunulabilir (Onur, 2011).

Yaşlılarla yürütülen psikolojik danışma yaklaşımlarından biri de dışavurumcu yaklaşımlardır. Klasik yaklaşımlarda olduğu gibi sözlü iletişimin zarurî olmadığı bu yaklaşımda, sözel iletişim becerisinde azalmalar görülen yaşıı bireylerle rahatlıkla çalışılabilir (Malchiodi, 2005). Yaratıcı sanatların terapi ortamında kullanımını sağlayan dışavurumcu yaklaşımlar, sanat terapisi, müzik terapisi, drama terapisi, dans ve hareket terapisi, şiir terapisi ve bibliyoterapi, oyun terapisi, kum oyunu terapisi ve entegre sanat yaklaşımı ya da disiplinler arası terapi gibi farklı alt dalları içermektedir (Yüksel, 2014). Yaşlı bireylerin iyi oluş düzeylerine olumlu katkı yapmayı sağlayacak dışavurumcu terapilerde bütün bu yaklaşımların yanında yaşlıyla hatıra defterleri hazırlama, öyküler yazma, bahçeyle uğraşma gibi etkinlikler de düzenlenebilir.

Yaşlılarla çalışan psikolojik danışmanlar farkındalık ve kabullenme temelli terapilerden de faydalanabilir. Dikkati şimdiki âna odaklama, berrak ve yargısız bir zihinle anlık deneyimlerin hüküm vermeden ve kabullenmeyle gözlemleme temeline dayanan bu yaklaşımda yaşlı bireyle yürüyüş meditasyonları, farkında okuma etkinlikleri, beden tarama çalışmaları, farkında nefes alma egzersizleri, kuru üzüm egzersizi, etiketleme, ara verme, durma ve sakinleşme, zihni 
durdurma gibi tekniklerden faydalanılarak yaşı bireyin farkındalığı artırılarak daha dingin bir yaşam oluşturmasına katkı sunulabilir (Demir-Çelebi, 2014).

Maneviyatın yaşlı bireylerin yaşamında önemli bir rolü vardır ve Amerika'da bütün yaş grupları içinde maneviyatla dine en bağlı olan grup yaşl1lardır (Hodge, Bonifas ve Chou, 2010; Lewis, 2001). Yapılan araştırmaların birçoğu din ve maneviyatın yaşlının beden ve ruh sağ l1ğını olumlu yönde etkilediğini göstermektedir (Horozcu, 2010; Dein ve Kimter, 2014). Bu açıdan bakıldığında yaşlı bireylere manevî danışmanlık sunulmasının faydalı olabileceği söylenebilir. Yaşlılara sunulan manevî danışmanlık uygulamalarında manevî gereksinimlerin ortaya konması, bireyin manevî potansiyelinin ortaya çıkarılması, tefekkür (düşünme-fikir), hissetme, vicdanî ve kalbî duyguların canlandırılmasına yönelik egzersizler yaptırılması, sabırla ve dikkatle yaşlı bireyin dinlenmesi, dinî günlerin ve ayların kutlanması, dinî kitabın okunması, ibadet ve dua saatleri oluşturulması, dinî filmler izlenmesi, dinî ve manevî müzik dinlenmesi, dinî mekânların ziyaret edilmesi ve dinî sohbetler yer alabilir (Seyyar, Karagöz, Aksu, Uçar ve Hamdemirci, 2009). Bazı araştırma sonuçları ise, olumsuz dinî tecrübelerin beden ve ruh sağlığına da olumsuz biçimde yansıdığ 1 bulgusunu sunmaktadır (Horozcu, 2010). Bu açıdan bakıldığında, yaşlı bireye pek çok yararı olduğu ortaya konan manevî danışmanlık yaklaşımları sunulurken profesyonellerin, tek bir dinî öğreti üzerinden gitmek yerine bütün dinlerin genel bakışının farkında olması ve olası bütün aksaklıklara ilişkin hassasiyet göstermesi önemli bulunmaktadır. 
Batı'da yapılan tek yönlü insan şahsiyeti tanımlarının Doğu'da farklılaştı̆ğ görülmektedir. Doğu kültüründe insan hem ebedî, hem de ezelî yönüyle ele alınmakta; bireyin psikolojik yönü kalp, nefs ve ruh bağlamında incelenmektedir. Şahsiyet gelişimi söz konusu olduğunda kişi, nefsin mertebelerine göre değerlendirilir ve nefsin en üst mertebesine ulaşılması yolunda bireyin sahip olduğu potansiyelin açığa çıkarılması için çalışılır. Nefsin mertebelerinin ele alınış biçimi incelendiğinde makam sayısına göre farklılaşmalar olduğu görülmektedir. Gazzali, Ataullah İskenderî, Ragıb el-Isfahani, Necmeddin-i Kübra ve Şihabüddin Sühreverdî gibi mutasavvıflar nefsi üçlü biçimde (emmâre, levvâme, mutmainne) ele alırken; Hâkim-i Tirmizî ve Eşrefoğlu Rumî gibi mutasavviflar dörtlü (emmâre, levvâme, mülhime, mutmainne); Osmanlı mutasavvıfları ise genellikle yedili bir sinıflandırma kullanmıştır (Muslu, 2007). Bu yedili tasnifte nefs, en alt mertebeden en üst mertebeye nefs-i emmare, nefs-i levvame, nefs-i mülhime, nefs-i mutmainne, nefs-i raziye, nefs-i marziye ve nefs-i kâmile şeklinde ele alınmaktadır (Yıldız, 2007). Yaşlılarla yürütülecek psikolojik danışma hizmetleri kurgulanırken Doğu kültüründe ele alınan bu şahsiyet tanımı ile gelişim evrelerinin göz önünde bulundurulması faydalı olabilir. Danışmanlık uygulamalarında, bireyin kendisini keşfetmesi ve nefsin mertebelerinde yükselmesi için gerekli uygulamalar gerçekleştirilerek daha huzurlu, saadet dolu bir yaşama sahip olmasına destek olunabilir.

\section{Sonuç ve Öneriler}

Yaşlı nüfûsun artmasıyla sosyal politikalar, hukukî düzenlemeler ve sosyal hizmetler geliştirilmiştir. Amerika'da ve Avrupa'da bu ko- 
nuda, yaşlının ekonomik ve sosyal anlamda desteklenmesi için birçok düzenleme yapılmıştır. Maddî yardım, eve yemek servisi, ücretsiz ulaşım, tele-yardım servisleri, yaşlı destek grupları yaşlılar için avantaj sağlamaktadır. Kurumsal bakımın psikososyal ve tıbbî anlamda yaşlı üzerindeki olumsuz etkileri, sosyal ilişki kurmada engel teşkil etmesi ve yaşlı bireyin özgür ifadesiyle çatışma yaratmasından dolayı Amerika, Avrupa ve İskandinav ülkelerinde 20. yüzyıldan itibaren alternatif bakım hizmetleri gelişmektedir. Ulusal Ev Bakım Servisi (Amerika)'nden elde edilen verilere göre, Amerika'da yaşlıya ev bakım ve destek hizmeti veren 15027 kuruluş olduğu görülmektedir. Bunun yanında, evde bakım hizmetlerinde çalışan personel sayısının yedi yüz bin olduğu ve her yıl bu hizmetten faydalanan otuz milyon kişi olduğu bilinmektedir (Danış, 2008). Yaşlıların hayatını düzenlemede kullanılan sistemler incelendiğinde, Avrupa Birliği ülkeleri arasında fark edilir bir çeşitlilik olduğu görülmektedir. Bazı ülkelerde (Belçika, Yunanistan, Lüksemburg, Portekiz ve İspanya gibi) yaşlıların kalması için ayrılmış yerlerin sayısı oldukça düşükken, Hollanda gibi ülkelerde bu sayının oldukça yüksek olduğu görülmektedir. Ancak bu ülkelerin çoğunda, hala ailede bakım ve sosyal ilişkilere oldukça önem verilmektedir (Wilderom, Nijkamp ve Vollering, 1990).

Türkiye'deki çalışmalara bakıldığında ise, sosyal sigortalar ve sosyal hizmetler konusunda çalışmaların olduğu görülmektedir. Aile ve Sosyal Politikalar Bakanlığı İl Müdürlükleri tarafindan yürütülen çalışmalarda yaşlilara da yer verilmiştir. Bununla beraber belediyelerin ve sivil toplum kuruluşlarının çeşitli projeler kapsamında yaşlılara hizmet 
sunan ve yaşlılarla gençleri bir araya getiren çalışmalarına (YÖRET Vakfi-Kuşaklar Köprüsü, Beşiktaş Belediyesi-Sosyal Alarm Projesi ve İzmir Büyükşehir Belediyesi-Gençler Yaşlılar Elele Projesi gibi) rastlanmaktadir.

Türk geleneksel yapısında yaşlıya verilen önemden dolayı huzurevinde yaşayan yaşlı sayısı hâlâ çok fazla değildir. Ancak, kadının çalışması ve çekirdek aile yapısına dönülmesiyle yaşlıların bakımında da güçlükler yaşanmaktadır. Bunun için yaşlılar, huzurevleri ve bakımevlerinde hayatlarına devam edebilmektedir. Yaşlılara yönelik çalışmalar daha çok, yaşlıların günlük ihtiyaçlarının karşılanması, tıbbî bakım ve tedavilerinin yapılması, sosyal ilişkilerinin geliştirilmesi, zamanlarının değerlendirilmesi, aktivitelerinin devamının sağlanması, ayrıca besin harcama oranları ve sağlık durumları göz önüne alınarak uygun tarzda beslenmelerinin temini ekseninde yürütülmektedir. Ancak bu bakım hizmetlerine bakıldığında, hizmetlerin sosyal ve psikolojik yönden birçok eksikliği olduğu görülmektedir.

Yaşlıların sosyal ve psikolojik yönden geliştirilmesi için psikolojik danışmanlık ve rehberlik hizmetlerinin artırılması gerekmektedir. Yetişkin bireyin yaşlılığa hazırlanması, yaşlının yaşadığı problemlerle başa çıkması, yaşılı bakımı yapan profesyonel elemanlar ve aile bireylerinin desteklenmesi ve güçlendirilmesi, yaşlıların toplumla uyum içinde huzurla yaşamalarını kolaylaştıracaktır. Yaşlılara sunulan psikolojik danışmanlık ve rehberlik hizmetlerinde yaşlılara bireysel ve grupla psikolojik danışma verilebileceği gibi; gençlerle yaşlıları bir araya getiren çalışmalar, yaşlıların hobi alanlarını kullanmasının sağ- 
lanması, kariyer plânlamalarının gözden geçirilmesi gibi rehberlik etkinliklerine de yer verilebilir.

Türkiye'de oluşturulacak yaşl1 psikolojik danışmanlığı hizmetlerinde kültürel ögelerin göz önünde bulundurulması önemlidir. Batı literatüründe geliştirilen uygulamaların birebir bu hizmetlere eklemlenmesi yerine, kültürel süzgeçten geçirilerek bütünleştirmenin sağlanması ve hatta kültürel motifleri içeren yeni uygulamaların oluşturulması yaşlıların ruh sağlığı gelişimlerine büyük fayda sağlayabilir.

Türkiye'de yaşlıya yönelik psikolojik danışma hizmetlerinin yaygınlaştırılmasında Aile ve Sosyal Politikalar Bakanlığı, Sağlık Bakanlığı, yerel yönetimler ve sivil toplum kuruluşlarının rolü büyüktür. Aile ve Sosyal Politikalar Bakanlığı'na bağlı yaşlıya hizmet veren kurumlarda rehberlik ve psikolojik danışmanlık uygulamalarına yer ve zaman ayrılması ile bu kurumlarda psikolojik danışmanların görevlendirilmesinin yaşlıların ruh sağlığı gelişimleri açısından faydalı olacağı söylenebilir. Gerek yaşı bakımı yapan kuruluşlarda psikolojik danışma ve rehberlik servisinin kurulması, gerekse yaşlıya hizmet veren başlı başına bir kurum oluşturulması (yaşlı danışma merkezi gibi) bu konuda atılacak önemli bir adımdır. Verilecek hizmetin verimli olabilmesi için psikolojik danışmanların amaca uygun bir biçimde eğitilmeleri gerekir. Böylece psikolojik danışmanlar aracılığıyla toplumda yaşlıların durumuna ve uygun yaklaşım tarzlarına ilişkin farkındalık sağlanabilir. Bu şekilde hem yaşlı birey hem de yaşlı bireylerle yaşayanlara kolaylıkla ulaşılarak ailelerin refah düzeylerine olumlu yönde katkı sunulabilir. Yaşlıya verilen hizmetlerin gözden geçirilmesi 
ve eksikliklerin tamamlanması, kaçınılmaz olan yaşlılıkta tüm bireylerin mutlu bir toplumda yaşamasını kolaylaştıracaktır.

\section{Kaynakça}

Akgün, S., Bakar, C. ve Budakoğlu, İ. (2004). Dünyada ve Türkiye'de yaşlı nüfus eğilimi, sorunları ve iyileştirme önerileri. Türk Geriatri Dergisi, 7(2), 105-110.

Altıntaş, H., Attila, S., Sevencan, F., Akçalar, S., Sevim, Y. ve Solak, S. (2006). Ankara'da bir yaşlı bakımevinde yaşayan yaşlılarda depresyon belirtilerinin taranması. TSK Kоrиуиси Hekimlik Bülteni, 5, 332-42.

Arslan, H. ve Bölükbaş, N. (2003). Huzur evinde kalan yaşlıların psikososyal yönlerinin incelenmesi. Düşünen Adam;16(4), 235-239.

Arslan, H. N. (2011). Yaşlıların yaşadıkları ortama göre yaşam kalitesi ve yaşam doyumu düzeylerinin karşılaştırılması. Yayınlanmamış tıpta uzmanlık tezi. On Dokuz Mayıs Üniversitesi.

Bacanlı, H. ve Işık-Terzi, Ş. (2013). Yetişkinlik ve yaşlılık gelişimi ve psikolojisi. İstanbul: Açılım Kitap.

Bahar, A., Tutkun, H. ve Sertbaş, G. (2005). Huzurevinde yaşayan yaşlıların anksiyete ve depresyon düzeylerinin belirlenmesi. Anadolu Psikiyatri Dergisi, 6, 227-39.

Can, G. (2012). Kişilik gelişimi. B. Yeşilyaprak, (Ed.), Eğitim psikolojisi. Gelişim-öğrenme-öğretim (9. bask1.) içinde (125-163). Ankara: Pegem Akademi.

Cinsel Eğitim Tedavi ve Araştırma Derneği. (2006). Cinsel Yaşam ve Sorunları. (Rapor No: 1). Şahin, D., Şimşek F. ve Seyisoğlu, H.: Editör.

Corey, G. (2008). Psikolojik danışma, psikoterapi kuram ve uygulamaları. (T. Ergene, Çev.). Ankara: Mentis Yayıncılık. (Orijinal çalışma basım tarihi 2005). 
Çevik-Sökmen, D. (2008). Huzurevinde kalan yaşllların huzurevindeki yaşamlarına ilişkin algıları. Yayınlanmamış yüksek lisans tezi. Marmara Üniversitesi, Eğitim Bilimleri Enstitüsü.

Danış, M. Z. (2008). Community based care understanding and social services: a care model proposal from Turkey. Turkish Journal of Geriatrics, 11(2), 94-105.

Dein, S. ve Kimter, N. (2014). Din, maneviyat ve depresyon: Tetkik ve tedavi için öneriler. Ekev Akademi Dergisi, 18(58), 739-750.

Demir-Çelebi, Ç. (2014). Farkındalık ve kabullenme temelli terapiler. A. N. Canel, (Ed.), Terapide Yeni Ufuklar 1. içinde (71-96). İstanbul: Pinhan.

Dönmez, G. (2010). Yaşlllarda yaşam kalitesini etkileyen faktörler. Yayınlanmamış yüksek lisans tezi. Abant İzzet Baysal Üniversitesi Sağlık Bilimleri Enstitüsü.

Ersanl1, E. (2008). Yaşlıya bakım hizmetleri. K. Ersanlı ve M. Kalkan, (Ed.), Psikolojik, sosyal ve bedensel açıdan yaşlılık içinde (184-191). Ankara: Pegem Akademi.

Fortner, B.V. ve Neimeyer, R. A. (1999). Death anxiety in older adults: A quantitative review. Death studies. 23(5). 287-411.

Gladding, S. T. (2013). Psikolojik danışma. Kapsamlı bir meslek. Ankara: Nobel Yayın Dağıtım.

Göka, E. ve Aydemir, Ç. (2000). Yaşlyya ve demanslı hastaya psikososyal yaklaşım. Demans Dizisi, 1, 5-26.

Gökkoca, F. Z. U. ve Baharlıetiler, N. (1999). Yaşlılık döneminde hizmet programları. Hacettepe Üniversitesi Toplum Hekimliği Bülteni, 3(4),1-4.

Güven, S. ve Şener, A. (2010). Factors affecting life satisfaction in old age. Turkish Journal of Geriatrics, 14(2), 179-186.

Hodge, D. R., Bonifas, R. P. ve Chou, R. (2010). Spirituality and older 
adults: Ethical guidelines to enhance service provision in social work practice. Advances in Social Work, 11(1), 1-16.

Horozcu, Ü. (2010). Tecrübi araştırmalar ışı̆̆ında dindarlık ve maneviyat ile ruhsal ve bedensel sağlik arasındaki ilişki. Milel ve Nihal, 7(1), 209-240.

İçli, G. (2010). Yaşlılar ve yaşlılı̆̆ın değerlendirilmesi: Denizli ili üzerine niteliksel bir araştırma. Yaşlı Sorunları Araştırma Dergisi, 1, 1-13.

Karaca F. (2000). Ölüm psikolojisi. İstanbul: Beyan Yayınları.

Kaygusuz, C. ve Kalkan, M. (2008) Psikolojik, sosyal ve bedensel açıdan yaşlılık. K. Ersanlı ve M. Kalkan, (Ed.), Yaşlılık danışmanlığ içinde (251-295). Ankara: PegemA.

Lewis, M. M. (2001). Spirituality, counseling, and elderly: An introduction to the spiritual life review. Journal of Adult Development, 8(4), 231-240.

Malchiodi, C. A. (2005). Expressive therapies. History, theory, and practice. C. A. Malchiodi, (Ed.), Expressive therapies içinde (1-15). New York: Guilford.

Myers, J. (1995). From "forgotten and ignored" to standards and certification: Gerontological Asia's next challenge: Caring. Journal of Counseling and Development, 74(2), 143-149.

Morgan, A. C. (2003). Psychodynamic psychotherapy with older adults. Pscyhiatric Services, 54(12), 1592-1594.

Muslu, R. (2007). Halvetiyye'de "Atvâr-1 Seb'a" yazma geleneği ve Sofyalı Bâlî'nin Atvâr-1 Seb'a Risalesi. Tasavvuf: İlmî ve Akademik Araştırma Dergisi, 8(18), 43-63.

Mutlu, Z. (2012). Yaşlı bireylerde yaşam tatmini ve sosyal destek ilişkisinin incelenmesi. Yayınlanmamış yüksek lisans tezi. Gazi Üniversitesi Eğitim Bilimleri Enstitüsü. 
MacAdam, M. (2008). Frameworks of Integrated Care for the Elderly: A Systematic Review. CPRN Research Report. Canada: CPRN.

National Institute on Aging. (2007). Why population aging matters. A Global perspective. Report No. 07 - 6134. USA: NIA.

Onur, B. (2011). Gelişim psikolojisi yetişkinlik-yaşlılık- ölüm. Ankara: İmge Kitabevi.

Özer, M. (2001). Huzurevinde ve aile ortamında yaşayan yaşlıların öz bakım gücü ve yaşam doyumunun incelenmesi. Yayınlanmamış yüksek lisans tezi. Ege Üniversitesi Sağl1k Bilimleri Enstitüsü.

Özer, M. (2004). Huzurevinde veya aile ortamında yaşayan yaşlıların yaşam doyumunun incelenmesi. Türk Geriatri Dergisi, 7(1), 33-36.

Pollack, J. M. (1980). Correlates of death anxiety: A review of empirical studies. Omega. 10, 97-121.

Satre, D. D., Knight, B. G. ve David, S. (2006). Cognitive behavioral interventions with older adults: Integrating clinical and gerontological research. Professional Psychology: Research and Practice, 37(5), 489-498.

Seyyar, A., Karagöz, M., Aksu, F., Uçar, G. ve Hamdemirci, Z. (2009). Manevî bakım aktiviteleri: "Demanslı yaşlılar ile manevi bakım aktiviteleri. Demanslı Ylllara Değer Katan Aktiviteler içinde (s. 247-272). İstanbul: İstanbul Büyükşehir Belediyesi Basım evi.

Singh, A., Singh, D. ve Nizamie, S. H. (2003). Death and Dying. 12 Aralık 2014, http://www.gb42.com/ynotdeathanddying.html.

Siviş, R. (2007). Anımsama terapisi ve ileri yaştaki yetişkinlerle grupla psikolojik danışmadaki yeri. Türk Psikolojik Danışma ve Rehberlik Dergisi, 3(28), 129-138.

Subaşı, N. ve Öztek, Z. (2006). Türkiye'de karşılanamayan bir gereksinim: evde bakım hizmeti. TSK Koruyucu Hekimlik Bülteni, 5(1), 19-31. 
Substance Abuse and Mental Health Services Administration. (2012). Brief Interventions and Brief Therapies for Substance Abuse. (Rapor No: 34). Rockville: Treatment Improvement Protocol (TIP) Series.

Thompkins, M. A. (2007). Bilişsel-davranışçı terapide vaka formülasyonu. R. L. Leahy, (Ed.), Bilişsel terapi ve uygulamalart içinde (57-79). İstanbul: Litera.

Türkçapar, H. (2012). Bilişsel terapi- temel ilkeler ve uygulama. Ankara: HYB.

Wilderom, C. P. M., Nijkamp, P. ve Vollering, A. M. C. (1990). Services for the elderly in Europe: A cross-national comparative analysis. 10 Mart 2012, ftp://zappa.ubvu.vu.nl/19900066.pdf.

World Health Organization (2004). World population prospects: The 2002 revision population database. 10 Mart 2012, http://www.un.org/esa/population/publications/wpp2002/WPP2 002_VOL_3.pdf.

Yazıcıŏlu, S. (2010). Ege yaşl hizmet merkezinde verilecek sosyal hizmetin kuramsal ve yasal dayanağı. Akademik Geriatri 2010 Kongresi'nde sunulan bildiri. Akademik Geriatri Derneği, Magosa, 26-30 Mayıs.

Yüksel, M. (2014). Dışavurumcu Terapiler. A. N. Canel, (Ed.), Terapide Yeni Ufuklar 1. içinde (117-142). İstanbul: Pinhan. 